\title{
Transforming Waste and Residues
}

\author{
Ranu Chaturvedi
}

\begin{abstract}
Solid waste refers to any refuse, garbage, sludge from water supply treatment plants, wastewater treatment plants and other discarded materials which include solid, semi-solid, liquid or gases discharged from community activities as well as from commercial, agricultural, industrial and mining operations. There is an indiscriminate disposal of solid wastes generated by domestic, commercial and industrial activities. In Indian urban areas, wastes of all kinds and piles of garbage are littered everywhere. The rural areas have also not been spared from the menace of mounting garbage and associated hazards. With the expanding population coupled with wasteful consumerism and general ignorance regarding cleanliness, the symptoms of stress on the environment and living conditions are clearly evident in rural as well as urban areas of India.
\end{abstract}

\section{INTRODUCTION}

$\mathrm{D}$ ISPOSAL of municipal solid waste is generally done through open dumping or land filling which further leads to more landfill gases emissions and organic load on the ground water. Most of the Indian cities have shortage of land for dumping of wastes as most of the land-filling sites have been already over used. So there is an obvious need to reuse or recycle the urban waste. The technologies for recovery of energy and nutrients from such wastes can play a major role in eliminating the solid waste problems. Technologies that have been developed to manage solid wastes include biomethanation, sanitary land fill gas, pelletisation, pyrolysis/ gasification, composting and vermicomposting.

\section{REVIEW OF LITERATURE}

Advancement in the industrial development and increase in urbanization in the environment had created more chances for pollution, which in turn affects the normal life of all living system in the earth. For man's survival and activities, several industries were established and along with usable matter, several unwanted waste as effluent and sludge were released in large quantity and dumped in the environment polluting the surrounding. Most of the solid and liquid wastes found their ways in accumulating on soil and water ecosystem. Problems with the disposal of wastes can be traced from the time when humans first began to congregate in tribes, village and communities and the accumulation of waste becomes an inevitable part of living.

Ranu Chaturvedi, Department of P.G. Studies and Research in Chemistry and Pharmacy, Rani Durgavati University, Jabalpur-482001

DOI: $10.9756 / I J R A S .8140$

\section{Waste Water TReatMent AND SOLID WASte DISPOSAL}

In many developing countries, the water resources are heavily polluted, mainly with domestic wastes, both solid and liquid. Existing health risks from poor quality water are even higher in a country with great water consumption. The domestic wastewater is let out into the nearby surface water sources like streams and rivers. From there, they reach the nearby ground water sources. Thus public water supply systems and domestic wells are affected. Solid wastes like food residues, vegetable residues, etc. which are thrown away by people pollute the environment.

Shahul Hameed et al (2002) found that the method of utilization of organic material for land filling and traditional composting are inefficient. He recommended that the efficient alternative method for organic waste is vermicomposting.

Raiannan et al (2002) noticed that the increasing demand for the safe disposal of solid waste has resulted in the use of earthworms and microorganisms that make up the soil decomposer industry. Wastes with sufficient organic matter content are amenable for decomposition by earthworms.

Lotzof (1999) found that the reuse of sewage sludge, in very large scale vermiculture offers an ecologically and commercially sustainable alternative for composting or lime stabilization. It is pollution free, with no odor or leachate problems.

Edward Neuhauser et al (1984) found that vermin stabilization especially for liquid primary and waste activated sludge can be a technically and economically feasible alternative for sludge stabilization and can stabilize liquid sludge with a total solids contents as low as $0.6 \%$ as long as the liquid drains rapidly

Raghunatha Reddy et al (2002) found that the content of $\mathrm{N}, \mathrm{P}, \mathrm{K}$ increased over the period of composting and at the same time there will be a decline in the organic Carbon content and this leads to reduction of $\mathrm{C} / \mathrm{N}$ ratio over time. The castings of vermi-technology are produced relatively very quickly and efficiently than the old methods such as windrows, landfill etc. He recommended that the system must be maintained at temperatures below $35^{\circ} \mathrm{C}$, and the moisture around $60-70 \%$.

Dubey (1997) reported that the farmyard manure of soya bean and biofertilizers increased the total number of root nodules/plant. Vermicompost, which are stabilized organic materials produced by interactions between earthworms and microorganisms in a nonthermophilic process, have been reported to enhance in plant growth and yields in greenhouse crops (Edwards and Arancon, 2004; Edwards et al., 2004). Applications of vermicompost have also reported to increase growth and yield in pepper (Arancon et al., 2003, 2004). 
Atiyeh et al. (2000, 2002) reported more marigold flower buds in Metro Mix 360 substituted with pig manure vermicompost. Humic substances have been shown to increase yield of corn, oats, soya bean, peanuts, clover, chicory plants and other tropical crops (Lee and Bartlett, 1976; Cacco and Dell' Agnola, 1984; Albuzio et al., 1994; Hayes and Wilson, 1997; Muscolo et al., 1993, 1996, 1999).

\section{ThreAt to WetLAND ECo System}

The wetlands are currently subjected to acute pressure of rapid developmental activities and indiscriminate utilization of land and water. Consequently the system is being destroyed, especially in the tropics, at an alarming rate of one percent per year. Though there exists any or no quantitative estimate on the rate of destruction of wetlands in Kerala, the qualitative degradation of the ecosystem is more or less, well understood. Natural causes such as erosion, storm damage, drought, eutrophication and biotic interference also destroy the wetlands. Artificial wetlands are constructed to improve the quality of wastewater. The management of the wetlands includes treatment of the effluent discharge, regulating industrial growth, regulating port and fishing activities and improvement in transportation and modernization of coir industry. There is an immediate requirement of the stoppage of waste disposal in aquatic bodies. Integrated management of agricultural practices can regulate the excess usage of pesticides and chemical fertilizers.

\section{HOW WeTLAND IMPROVE WATER QUALITY}

Several studies have shown that wetlands reduce nitrogen and phosphorus concentrations in runoff and flood water to a significant extent by transforming them and releasing them into the atmosphere. High proportions of suspended solids make a water cloudiness which prevents downstream ecosystems from entering the wetlands. Moreover several pollutants affecting water quality are often absorbed onto these suspended solids, thus removing pollutants from water while the sediment deposit itself provide multiple benefits to downstream water quality.

\section{IMPORTANCE OF VERMICOMPOSTING}

Vermicomposting is a biotechnological process in which earthworms are employed to convert the organic wastes into humus 10 like material known as vermicompost. Certain earthworm species are capable of consuming a wide range of organic wastes from sewage sludge, animal wastes, agricultural residues, domestic wastes, to industrial wastes. Under favourable conditions of temperature and moisture, earthworms maintain the aerobic conditions in the vermicomposting process ingest organic waste materials and egest a humus-like substance which is more homogeneous than the organic wastes or raw materials used (Arancon et al. 2003; Edwards and Burrows 1988). The actions of the earthworms in this process are both physical and biochemical. The physical actions include fragmentation, turnover and aeration. Whereas biochemical actions include enzymatic digestion, nitrogen enrichment, transport of inorganic and organic materials (Edwards and Lofty 1972). During this process, important plant nutrients such as nitrogen, potassium, phosphorus and calcium present in the waste materials are converted through microbial action into such chemical forms which are much more soluble and available to the plants than those in the parent substrate (Ndegwa and Thompson 2001).

\section{VERMICOMPOSTING}

Vermicomposting has been arising as an innovative ecotechnology for the conversion of various types of wastes into vermicompost. Vermicompost is humus like, finely granulated and stabilized material which can be used as a soil conditioner to reintegrate the organic matter to the agricultural soils. Industrial wastes remain largely unutilized and often cause environmental problems like ground and surface water pollution, foul odours, occupying vast land areas etc.

\section{RECYCLING/RECOVERY/REUSE}

Vishwanath and Anantha Murthy (2004) reported that 70$80 \%$ of waste is recyclable in nature of which, $20 \%$ is organic waste, $20 \%$ papers, $34 \%$ building waste material and the remaining $26 \%$ includes plastics $(10 \%)$, metal $(6 \%)$, rubber and leather (5\%) and glass (5\%). Lavanya and Venkatakrishnan (1997) suggested to the farming community that in a polluted environment where purity of soil and waste becomes bleak, it is advisable to use a bio-geo resource friendly earthworm which can sustain the environmental health as well pay much dividends to the farming community by reducing their fertilizer bill.

\section{CONVERTING Waste InTO BioEnergy}

Global food processor Remo-Frit utilises an innovative waste treatment system that turns effluent and solid residues from its operations into biogas, which is then converted to electricity

\section{CONCLUSION}

It is therefore necessary to improve the nutrient status of rural and urban wastes to reduce the pollution load. There are various possible ways to improve the nutrient status of urban and rural wastes. The rich bio-mass can be converted into bioenergy in the form of rich organic manure that can be utilized for meeting the energy needs of our crops. There is a need for abating or degrading and disposing the solid waste. With the advance of scientific approaches, several investigations were attempted to alleviate these impacts by physical, chemical and biological processes. Among the biological process, the process vermicomposting is the best one in which certain 29 earthworms can do the bio-remediation function like degrading and decomposing the waste from the agricultural and certain industrial waste.

\section{REFERENCE}

[1] Agdag, O.N. and Sponza, D.T. "Co-Digestion of Industrial Sludge with Municipal Solid Wastes in Anaerobic Simulated Landfilling Reactors", Process Biochemistry, Vol. 40, pp. 1871-1879, 2005.

[2] Agdag, O. N. and Sponza, D.T. "Co-digestion of Mixed Industrial Sludge with Municipal Solid Wastes in Anaerobic Simulated Landfilling Bioreactors", Journal of Hazardous Materials, Vol. 140, pp. 75-85, 2007. 
[3] Ahring, B. K. and Westermann, P. "Product Inhibition of Butyrate Metabolism by Acetate and Hydrogen in a Thermophilic Coculture", Applied and Environmental Microbiology, Vol. 54, pp. 2393 - 2398, 1988.

[4] Ahring, B.K., Sandberg, M. and Angelidaki, I. "Volatile Fatty Acids as Indicators of Process Imbalance in Anaerobic Digesters", Appl. Microbiol. Biotechnol., Vol. 43, pp. 559-565, 1995.

[5] Alatriste, M. F., Samer, P., Cox, H., Ahring, B. and Iranpour, R. "Anaerobic Co-digestion of Municipal, Farm, and Industrial Organic Wastes: a Survey of Recent Literature". Water Environ. Res., Vol. 78, No. 6, pp. 607-636, 2006.

[6] Alexis Mottet, Emilie François., Eric Latrille., Jean Philippe Steyer., Stéphane Déléris., Fabien Vedrenne and Hélène Carrère. "Estimating Anaerobic Biodegradability Indicators for Waste Activated Sludge", Chemical Engineering Journal, Vol. 160, pp. 488-496, 2010.

[7] Alvarez, J.A. Otero, L. and Lema J.M. "A Methodology for Optimizing Feed Composition for Anaerobic Co-digestion of Agro Industrial Wastes", Bioresource Technology, Vol. 101, pp. 1153-1158, 2010. 